\title{
Forthcoming Conferences / CALl for Papers
}

\author{
Hugoye: Special Issue on Women
}

[1] The editors of Hugoye invite submissions for a special issue marking the 1500th anniversary of the birth of the Empress Theodora, scheduled to appear in July 2001. One of the most venerated women of Syriac tradition, Theodora stands as a reminder that women have played crucial roles in the history of Syriac tradition. Yet our knowledge of women in this history remains sorely limited, having received limited scholarly attention thus far. In the apparent absence of any surviving Syriac texts authored by women (with one or two exceptions only), the task of recovering women's history in Syriac Christianity is a difficult one.

[2] Hugoye takes the occasion of Theodora's anniversary to call for new studies on the women of Syriac history in her honor. Tentatively entitled "Great Women in the Syriac Heritage," the issue will be devoted to articles that deal with major female figures in the history of Syriac tradition and with issues of women's place and roles in Syriac Christianity. Papers are welcome in all time periods of Syriac tradition, and in all religious identities.

Submissions should be sent to the Editor, George Kiraz, following the guidelines available at the Hugoye website. To be considered for the special issue marking Theodora's anniversary, submissions should be received by April 1, 2000. 
The Peshitta: Its Use in Literature and Liturgy

Third Peshitta Symposium, Leiden, 12-15 August 2001

Second Announcement and Call for Papers

\section{KONRAD D. JENNER AND R. BAS TER HAAR ROMENY, The PEShitTA INSTITUTE, LEIDEN}

[1] At the end of the fifties, the Leiden Peshitta Institute undertook the publication of the Peshitta of the Old Testament on behalf of IOSOT. Fourteen volumes have been published so far and four more are to come. In addition, several detailed studies of the text of Peshitta manuscripts have given us a picture of the development of the Peshitta text. There is, however, still another important desideratum. Right at the beginning of the project, it was noted that a much better knowledge of the Old Testament texts preserved in the patristic literature of the Syriac Churches was a prerequisite for obtaining a full picture of the text history. The lack of critical editions of a large part of this literature forbade inclusion of this material at that stage.

We believe that the moment has come to fill this gap. As much progress has been made on the Syriac Fathers in the intervening years, it is time to see where we stand: what has been done so far in this respect, what should be done, and how can we integrate the results of this research into the picture that has been formed on the basis of the study of Bible manuscripts?

Connected to these are a number of other questions. Peshitta scholars have come to appreciate the importance of providing a context for the textual history of the Peshitta. On the one hand, this is the context of church history. Peshitta manuscripts should be linked, if possible, to their place of origin or use. The development of the text is an event within the history of the Syriac Churches. The witness of the Syriac Fathers can also be of great importance in this respect. On the other hand, we should think of the history of exegesis and liturgy. It is not only the text of the readings that is of interest; we should also investigate the way the Peshitta was received and assessed by its users, whether in exegetical or historical literature or in liturgy.

This set of questions is the subject of the Third Peshitta Symposium, to be held in Leiden just after the Basel IOSOT Conference of 2001. It is our hope that during this Symposium 
attention will also be paid to the New Testament. We think that the issues mentioned above will be of relevance for the Old as well as the New Testament.

Keynote speakers include Professors Sebastian P. Brock, Luk Van Rompay, and William L. Petersen.

Colleagues and students in the field of Syriac studies are invited to participate in this Symposium. Those intending to attend and/or read a paper are kindly requested to return the registration form and/or to submit the title before 1 March 2001. Then we will consider the possibility of clustering papers and preparing some workshop(s). An abstract of about 350 words should be delivered before 30 April 2001. You are expected to deliver the provisional text of the paper at the conference. This is the only call for papers.

The Symposium will be held in Oud Poelgeest, a small castle near Leiden. The costs are fl. 700-, (i.e. fl. 250-, conference fee plus f. 450-, accommodation). All meals are included. We will do our best to find financial support in order to offer students a reduction. 
The Canadian Society for Syriac Studies: Schedule of Public Lectures

\title{
AMIr HARRAK, UnIVERSity OF TORONTO, CANADA
}

The following lecture series will be held at the University of Toronto under the auspices of The Canadian Society for Syriac Studies during 2001 First Quarter. The venue for all lectures is:

\author{
Auditorium, Earth Sciences Centre \\ Room 1050, 5 Bancroft Avenue \\ St. George Campus, University of Toronto
}

\section{Syriac Christianity in the Egyptian Desert: Recent Discoveries in the Monastery of the Syrians (Wadi al-Natrun)}

\section{Lucas Van Rompay, Duke University}

8.00 PM, Thursday, January 25, 2001

[2] The Egyptian desert always exerted a strong attraction on the Christians of Syria and Mesopotamia. Since the 9th century, West Syriac monks, supported by the wealthy people of Takrit among many others, settled in a monastery there, which became known as the "Monastery of the Syrians." Later, monks from the Lebanon and the region of Damascus demonstrated interest in that monastery up until the 17 th century, when the edifice became entirely Coptic again, although the name remained "Deir al-Surian." Here, Dutch, Polish and Egyptian scholars of art and conservation have been working in the main church since 1995, where they uncovered under the plaster an impressive number of wall paintings and Syriac inscriptions. Taking these discoveries into consideration, we shall talk about the history of the monastery, its role as centre of artistic and intellectual creativity, and as a place of encounter and interchange between the Syriac and the Coptic cultures.

\section{Mar Tadros, Bahdeidat: A Visit to a Lebanese Church in the Thirteenth Century}

Erica Dodd, Victoria University

8.00 PM, Thursday, February 15, 2001

[3] During the Crusades in the thirteenth century, Christians in the Lebanon prospered and there was a revival of church building. Lebanese Christians acted as intermediaries between the Crusaders 
and the Arab Muslims, profiting greatly from their favoured status in local society. In their position as middlemen, they engaged actively in the transfer of goods from along the silk route to the seaports and across the Mediterranean. This prosperity led to the building of churches and their decoration in Christian strongholds along the coast and in the mountains. One of these churches is the little church of Mar Tadros in the village of Bahdeidat, in the foothills just above Jubeil. This paper will illustrate the paintings in this Church and examine them in the context of other paintings in this region, in order to under-stand how the Christians of Lebanon interpreted their religion and their liturgy in the Middle Ages.

\section{Syriac Heritage on the Northern Silk Road: The Archaeological and Epigraphic Evidence of Christianity in Kirghizia}

\section{Wassilios Klein, Bonn University}

8:00 PM, Thursday, March 29, 2001

Since the 1890s Kirghizia has attracted the attention of scholars in the field of Syriac epigraphy, when Daniel Chwolson published about 600 Syriac funerary inscriptions found there. The discovery of these inscriptions came as a surprise since there was little literary evidence that Christianity had played any important role in the lands located to the north of the Tianshan Mountains. In recent years archaeological excavations in the Middle Age capital revealed a church with three naves and the grave of a holy man. Taking into consideration these excavations, the other religions coexisting with Christianity in Central Asia, and the political history of that region at that time, we shall describe the role played by East Syriac (socalled Nestorian) Christianity and the Syriac language in the daily life of the Sogdian and Turkish people.

Membership in the Canadian Society for Syriac Studies includes free admission to public lectures, an annual symposium, and subscriptions to the CSSS Bulletin, which will include the transcripts of the public lectures.

Annual regular member: US\$35.00

Please make cheques payable to the CSSS, and mail to:

CSSS c/o Dept. of Near and Middle Eastern Civilizations

4 Bancroft Avenue, Toronto

Ontario, Canada M5S 1C1. 


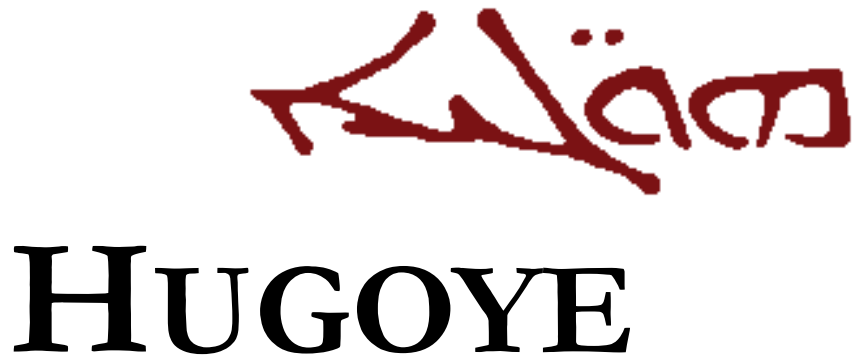

\section{JOURNAL OF SYRIAC STUDIES}

A Publication of Beth Mardutho: The Syriac Institute

SPECIAL ISSUE:

WOMEN IN THE SYRIAC TRADITION

Guest Editor

Susan Ashbrook Harvey 
